\title{
Thermal and Mechanical Properties of Sn-8Zn-3Bi Solder Alloy
}

Tính chất cơ và nhiệt của hợp kim hàn Sn-8Zn-3Bi

\author{
Duong Ngoc Binh \\ Hanoi University of Science and Technology, Hanoi, Vietnam \\ Email: binh.duongngoc@hust.edu.vn
}

\begin{abstract}
Thermal and mechanical properties of Sn-8Zn-3Bi solder alloy on copper substrate were evaluated via measuring the melting temperature, the coefficient of thermal expansion (CTE), the tensile and shear strength of the solder joint. The measured properties of the alloy were then compared to the properties of the traditional and widely used eutectic Sn-37Pb solder alloy. The results show that the melting (liquidus) temperature of $\mathrm{Sn}-8 \mathrm{Zn}$-3Bi was $195{ }^{\circ} \mathrm{C}$, the CTE of Sn-8Zn-3Bi was $22.2 \times 10^{-6} \mathrm{~K}^{-1}$ in the temperature range of $30-130{ }^{\circ} \mathrm{C}$. At the same testing condition, both tensile and shear strength of Sn-8Zn-3Bi joints were higher than those of $\mathrm{Sn}-37 \mathrm{~Pb}$. The stress-strain curve indicated that the Sn-8Zn-3Bi joints were brittle whilst the Sn-37Pb joints were ductile.
\end{abstract}

Keywords: Solder alloy, thermal properties, mechanical properties

Tóm tắt

Bài báo trình bày kết quả kiểm tra một số tính chất của hợp kim hàn không độc Sn-8Zn-3Bi để đánh giá khả năng sử dụng hợp kim này thay thế cho hợp kim hàn truyền thống Sn-37Pb. Các tính chất được xác định bao gồm nhiệt độ nóng chảy, hệ số giãn nở nhiệt, giới hạn bền kéo và giới hạn bền cắt của mối hàn hợp kim. Kết quả cho thấy trong khoảng nhiệt độ làm việc từ 30-130 ${ }^{\circ} \mathrm{C}$, hợp kim hàn Sn-8Zn-3Bi có hệ số giãn nở nhiệt là $22,2 \times 10^{-6} \mathrm{~K}^{-1}$. Nhiệt độ nóng chảy hoàn toàn (nhiệt độ lỏng) của hợp kim Sn-8Zn-3Bi là $195{ }^{\circ} \mathrm{C}$. Cả giới hạn bền kéo và giới hạn bền cắt của Sn-8Zn-3Bi đều cao hơn của Sn-37Pb. Đường cong ứng suất - biến dạng cho thấy phá hủy của mối hàn sử dụng hợp kim Sn-8Zn-3Bi là phá hủy giòn so với phá hủy dẻo của mối hàn sử dung Sn-37Pb.

Từ khóa: Hợp kim hàn, tính chất nhiệt, tính chất cơ học

\section{Introduction}

Legislation is driving major changes in the manufacture of electrical and electronics equipment. The most significant change is the elimination of lead from solder joints [1-3]. With the requirement to install lead-free solder processes, companies have a choice of alloys. As the selection process does not have any detailed requirement on the alloy's property (only reliability test included), some solder alloys are being used without fundamental knowledge of the alloys [4]. Consequently, some lead-free solders are commercially available but have not yet been fully characterized. Therefore, further study on such alloys remains an important issue.

When trying to identify an alternative to the current $\mathrm{Pb}-\mathrm{Sn}$ solders that are widely used, it is important to ensure that the properties of the replacement solder are comparable to or superior to $\mathrm{Pb}-\mathrm{Sn}$ solders. The major performance characteristics of solders that are of importance for packaging applications are manufacturability and reliability. Manufacturability describes how well a $\mathrm{Pb}$-free solder fits into current packaging practices without requiring significant changes. Manufacturability involves most of the physical properties of a solder alloy relevant to soldering such as melting temperature, solderability, viscosity, density, thermal and electrical properties, corrosion and oxidation behavior, surface tension, rework-ability, and cost [5-9]. The reliability of a solder alloy for packaging is mainly dependent on the coefficient of thermal expansion, elastic modulus, yield strength, shear strength, fatigue, and creep behavior of the alloy [10-14].

The $\mathrm{Sn}-8 \mathrm{Zn}-3 \mathrm{Bi}$ was a commercially available solder alloy that has been used for some time. Initially, the Sn-9Zn alloy was proposed due to its safety (leadfree), availability, and low cost. The eutectic Sn-9Zn also has a low melting point suitable for use as a solder alloy in electric and electronic equipment. It also possesses the advantages of high strength, good creep resistance, and high thermal fatigue resistance [15]. However, poor wetting and non-wetting were observed in Sn-9Zn during soldering due to the poor oxidation resistance of the alloy [16]. By adding Bi

ISSN 2734-9381

https://doi.org/10.51316/jst.154.etsd.2021.31.5.11

Received: December 17, 2020; accepted: June 23, 2021 
into $\mathrm{Sn}-\mathrm{Zn}$ solders, the wettability and corrosion performance of $\mathrm{Sn}-\mathrm{Zn}$ solders could be improved [15].

The wettability of $\mathrm{Sn}-8 \mathrm{Zn}-3 \mathrm{Bi}$ on copper was evaluated via measuring the contact angle of the solder alloy on the copper substrate [17]. In this work, other important properties of $\mathrm{Sn}-8 \mathrm{Zn}-3 \mathrm{Bi}$ alloy such as melting temperature, coefficient of thermal expansion, tensile and shear strength of the solder joint were evaluated.

\section{Experiment}

The copper substrate used in this study was the commercial copper foil of $1.5 \mathrm{~mm}$ in thickness and has a purity of $99.9 \%$. The solder alloys used were commercially available $\mathrm{Sn}-8 \mathrm{Zn}-3 \mathrm{Bi}$ and $\mathrm{Sn}-37 \mathrm{~Pb}$.

Sn-8Zn-3Bi samples used in CTE experiment were cut from the $\mathrm{Sn}-8 \mathrm{Zn}-3 \mathrm{Bi}$ solder bar. It was polished to the dimension of $20 \mathrm{~mm}$ in length, $3 \mathrm{~mm}$ in width and $3 \mathrm{~mm}$ in thickness. CTE of samples was measured by using a Dilatometer.

Tensile and shear specimen were prepared with the copper substrate as shown in Fig. 1.

(a)

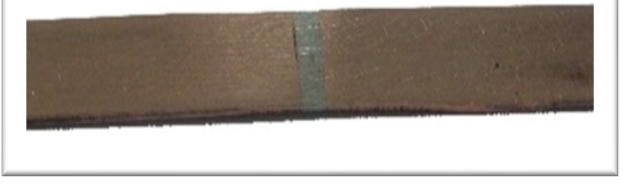

(b)

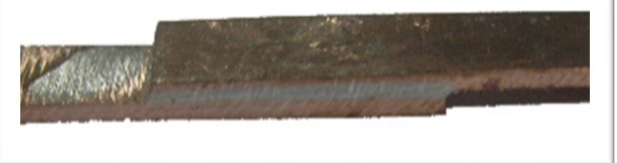

Fig. 1. a) Tensile specimen and b) Shear specimen

Copper sheet of $1.5 \mathrm{~mm}$ in thickness was cut in rectangular of $50 \mathrm{~mm}$ in length and $10 \mathrm{~mm}$ with. After that, the substrate was cleaned with abrasive paper and compressed air. To perform the solder joint, solder paste was loaded between two copper coupons then heated over the melting temperature of solder alloy by an electronic heater. After the solder alloy melted and spread between two copper coupons, The system is then cooled in air. The specimens obtained were cleaned to form the testing samples.

\section{Results and Discussions}

\subsection{Melting Temperature}

Fig. 2 shows the Differential Scanning Calorimetry (DSC) curve obtained from Sn-8Zn-3Bi specimen. A simple curve that shows no phase transformation of the alloy from room temperature until the melting temperature. The alloy started melting at a temperature of approx. $190{ }^{\circ} \mathrm{C}$. The onset temperature was approx. $195{ }^{\circ} \mathrm{C}$. The onset temperature of DSC curve can be admitted as the liquidus temperature of sample alloy [18]. Thus, the alloy's melting range was from 190 to $195^{\circ} \mathrm{C}$.

An advantage of low melting temperature solder alloy is the prevalent usage of thermoset polymers in microelectronics packaging. Epoxy resins are used for encapsulation, substrates, and attaching the silicon die to carriers or substrates, i.e., the die attach material. Currently, the highest temperatures that these polymeric materials are exposed to is approximately $230^{\circ} \mathrm{C}$ for $90 \mathrm{~s}$ [4], during board-level assembly and/or the reflow of solder balls and solder bumps. The Sn$8 \mathrm{Zn}-3 \mathrm{Bi}$ which has a melting temp of $195^{\circ} \mathrm{C}$, close to the melting temperature of the traditional $\mathrm{Sn}-37 \mathrm{~Pb}$ $\left(183^{\circ} \mathrm{C}\right)$ could be used as an alternative alloy in actual soldering without any change of equipment.

\subsection{Coefficient of Thermal Expansion}

The coefficient of thermal expansion (CTE) of $\mathrm{Sn}-8 \mathrm{Zn}-3 \mathrm{Bi}$ measured when temperature varies from $30{ }^{\circ} \mathrm{C}$ up to $130{ }^{\circ} \mathrm{C}$ is shown in Fig. 3 .

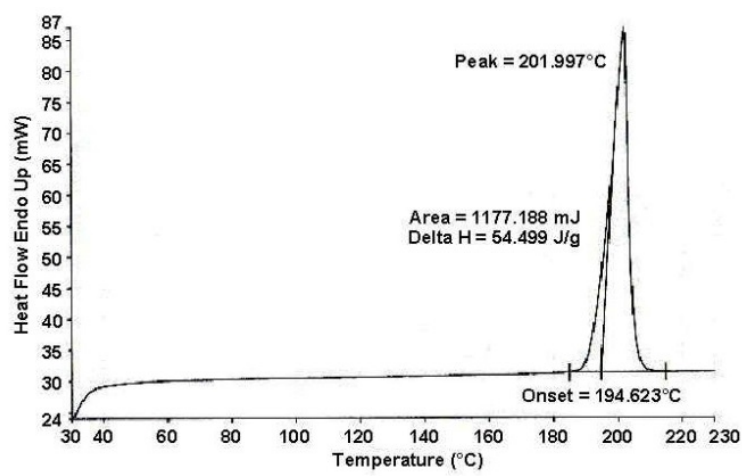

Fig. 2. DSC curve of Sn-8Zn-3Bi

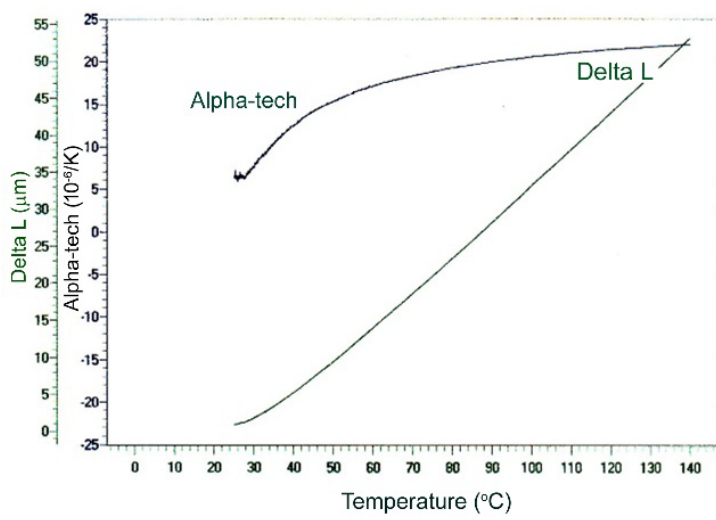

Fig. 3. Expansion of specimen (Delta L) and CTE of Sn-8Zn-3Bi

As can be seen, CTE of Sn- $8 \mathrm{Zn}-3 \mathrm{Bi}$ alloy increased as the temperature increases up to $130{ }^{\circ} \mathrm{C}$. Firstly, the CTE increases quite rapidly, $7.51 \times 10^{-6} \mathrm{~K}^{-1}$ up to $12.53 \times 10^{-6} \mathrm{~K}^{-1}$. However, the change of CTE becomes slow at a higher temperature. The increase in sample length is almost linear up to $140{ }^{\circ} \mathrm{C}$. In order to compare with the eutectic $\mathrm{Sn}-37 \mathrm{~Pb}$ solder alloy, the 
CTE experiment is also carried out with the traditional eutectic alloy, the obtained results are shown in Fig. 4 and Fig. 5.

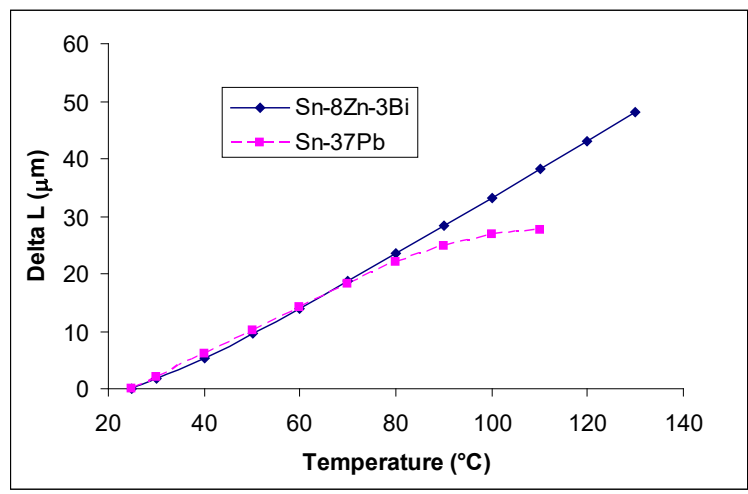

Fig. 4. Expansion of $\mathrm{Sn}-8 \mathrm{Zn}-3 \mathrm{Bi}$ and $\mathrm{Sn}-37 \mathrm{~Pb}$ Specimen

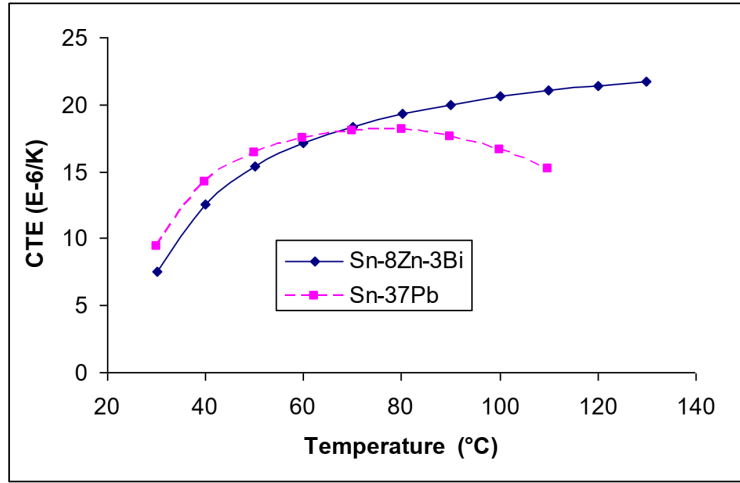

Fig. 5. CTEs of Sn-8Zn-3Bi and Sn-37Pb

The expansions in both solders are very similar up to $80{ }^{\circ} \mathrm{C}$. However, a significant difference started at $90{ }^{\circ} \mathrm{C}$ where $\Delta \mathrm{L}$ of $\mathrm{Sn}-8 \mathrm{Zn}-3 \mathrm{Bi}$ was $28.26 \mu \mathrm{m}$ while it was $24.86 \mu \mathrm{m}$ in $\mathrm{Sn}-37 \mathrm{~Pb}$. The difference of $\Delta L$ at $90{ }^{\circ} \mathrm{C}$ was $3.4 \mu \mathrm{m}$ and it increased when temperature increases. At $110{ }^{\circ} \mathrm{C}$ (ended temperature of $\mathrm{Sn}-37 \mathrm{~Pb}$ sample), $\Delta L$ of $\mathrm{Sn}-8 \mathrm{Zn}-3 \mathrm{Bi}$ sample was $38.14 \mu \mathrm{m}$ and it was $27.56 \mu \mathrm{m}$ in $\mathrm{Sn}-37 \mathrm{~Pb}$. The difference was increased to $10.58 \mu \mathrm{m}$.

The comparison of CTEs also shows the similarity between $\mathrm{Sn}-8 \mathrm{Zn}-3 \mathrm{Bi}$ and $\mathrm{Sn}-37 \mathrm{~Pb}$ up to $80{ }^{\circ} \mathrm{C}$ (Fig. 5). Above $80{ }^{\circ} \mathrm{C}$, the CTE of Sn- $8 \mathrm{Zn}-3 \mathrm{Bi}$ was continued to increase as temperature increased but it was reduced in $\mathrm{Sn}-37 \mathrm{~Pb}$. The maximum value of CTE of $\mathrm{Sn}-37 \mathrm{~Pb}$ was $18.07 \times 10^{-6} \mathrm{~K}^{-1}$ at $80{ }^{\circ} \mathrm{C}$ and it reduced to $17.57 \times 10^{-6} \mathrm{~K}^{-1}$ at $90{ }^{\circ} \mathrm{C}$ and $15.16 \times 10^{-6} \mathrm{~K}^{-1}$ at $110{ }^{\circ} \mathrm{C}$. Conversely, CTE of Sn-8Zn-3Bi kept increasing and reaches $27.41 \times 10^{-6} \mathrm{~K}^{-1}$ at the ended temperature of $130{ }^{\circ} \mathrm{C}$. CTEs of $\mathrm{Sn}-8 \mathrm{Zn}-3 \mathrm{Bi}$ and $\mathrm{Sn}-37 \mathrm{~Pb}$ solder alloys are in the same range, which is close to CTE value of copper, $16-18 \times 10^{-6} \mathrm{~K}^{-1}$ [4].

As can be seen in Fig. 3, $\Delta L$ of $\mathrm{Sn}-8 \mathrm{Zn}-3 \mathrm{Bi}$ increased almost linear fit with the increasing of temperature. If we assume that the increase of $\Delta L$ is linear fit, an average value, $\alpha_{L}$, of CTE can be calculated and can be applied through the range of temperature.

The expansion of the sample at a certain temperature can be expressed as follows:

$$
\Delta L=\alpha_{L} L_{0} \Delta T
$$

where $L_{0}$ is the length of the sample at $T_{0}$.

From the obtained values, the equations of the linear-fit lines have been calculated:

$$
\Delta L=0.444 \times 10^{-6} \Delta T
$$

From (1), (2), and $L_{0}=20 \mathrm{~mm}$ we have:

$$
\alpha_{L}=\frac{0.444 \times 10^{-6}}{20 \times 10^{-3}}=22.2 \times 10^{-6} \mathrm{~K}^{-1}
$$

These average values of CTE were used to recalculate $\Delta L$. Results are shown in Fig. 6. As can be seen, the line of calculated values is very close to the line of measured values for $\mathrm{Sn}-8 \mathrm{Zn}-3 \mathrm{Bi}$. Therefore, at the range of temperature and for engineering purposes, we can take the value $22.2 \times 10^{-6} \mathrm{~K}^{-1}$ as CTE of Sn-8Zn-3Bi.

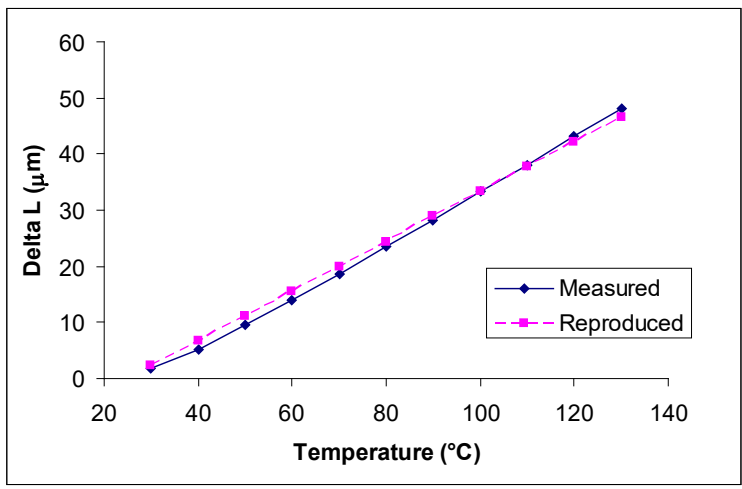

Fig. 6. $\Delta \mathrm{L}_{\text {measured }}$ and $\Delta \mathrm{L}_{\text {reproduced }}$ of $\mathrm{Sn}-8 \mathrm{Zn}-3 \mathrm{Bi}$

\subsection{Tensile Strength of the Solder Joint}

Tensile strength of solder joint depends on various factors, including cooling rate [19], strain rate [20], etc... Therefore, it is difficult to have a meaningful value of tensile strength of solder alloys. For comparison, the tensile strength of $\mathrm{Sn}-8 \mathrm{Zn}-3 \mathrm{Bi}$ and $\mathrm{Sn}-37 \mathrm{~Pb}$ under the same experimental conditions were measured. Results are shown in Fig. 7.

The tensile strength of $\mathrm{Sn}-8 \mathrm{Zn}-3 \mathrm{Bi}$ lead-free solder is higher than that of $\mathrm{Sn}-37 \mathrm{~Pb}$ eutectic solder. The measurements at two crosshead speeds of $0.1 \mathrm{~mm} / \mathrm{min}$ and $1 \mathrm{~mm} / \mathrm{min}$ are shown similar results. At the first crosshead speed, $0.1 \mathrm{~mm} / \mathrm{min}$, UTS of Sn$8 \mathrm{Zn}-3 \mathrm{Bi}$ has a value of $36.8 \mathrm{MPa}, 3.3 \mathrm{MPa}$ higher than that of $\mathrm{Sn}-37 \mathrm{~Pb}$. UTS increased when crosshead speed increased, it was $47.8 \mathrm{MPa}$ at a crosshead speed of $1 \mathrm{~mm} / \mathrm{min}, 5.6 \mathrm{MPa}$ higher than $\mathrm{Sn}-37 \mathrm{~Pb}$.

The stress-strain curve (Fig. 8) shows that the stress in Sn-8Zn-3Bi sample increased almost linearly 
up to $35 \mathrm{MPa}$. The linear fit part of $\mathrm{Sn}-37 \mathrm{~Pb}$ curve is just up to around $20 \mathrm{MPa}$. However, the Young Module (Elastic Module) of Sn-8Zn-3Bi is somewhat lower than that of $\mathrm{Sn}-37 \mathrm{~Pb}$.

An SEM image of the fracture surface of the Sn-8Zn-3Bi tensile specimen is shown in Fig. 9. The fracture surface can be divided into two areas, the brittle area at the edge of the specimen and the dimple pattern typical in overstress fracture of ductile material in the center of the specimen.

The result indicates that the failure is in brittle manner at the edge while it is ductile in the center of the solder joint. There is no significant plastic deformation before failure as the stress in the stressstrain curve reduced vertically when the $\mathrm{Sn}-8 \mathrm{Zn}-3 \mathrm{Bi}$ sample break (Fig. 8). Brittle failure was the principal failure of the Sn-8Zn-3Bi sample. Since the testing specimen was allowed to cool in the air, a fast cooling rate at the outer side of the specimen might have caused the embrittlement. Reducing the cooling rate could have eliminated the brittle phenomena of the joint.

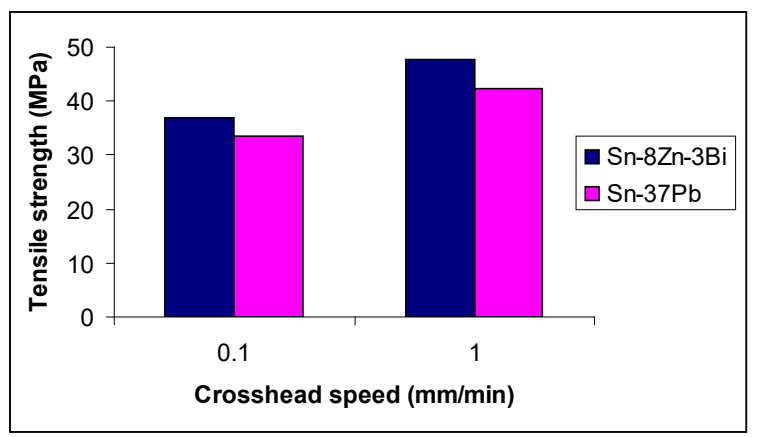

Fig. 7. Tensile strengths of solder alloys

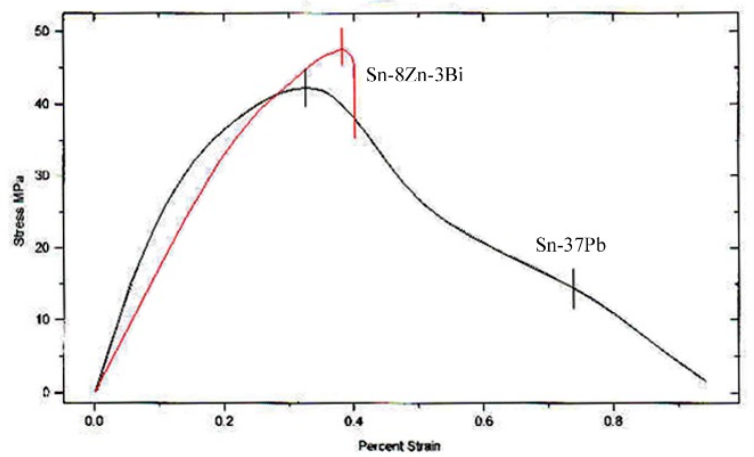

Fig. 8. Stress-Strain curves of solder alloys

The macro image of the broken specimens is shown in Fig. 10.

It can be seen that the solder-substrate joint was broken right at the interface and there is no significant plastic deformation was detected before failure.

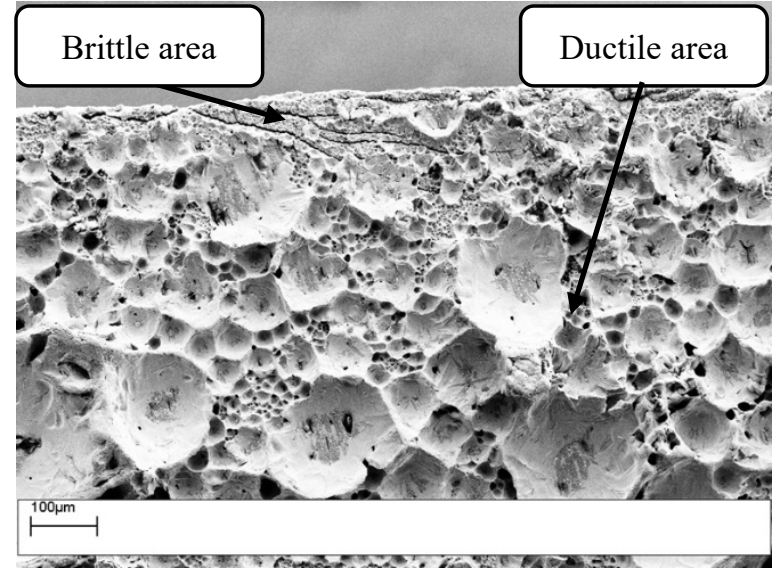

Fig. 9. SEM image of fracture surface

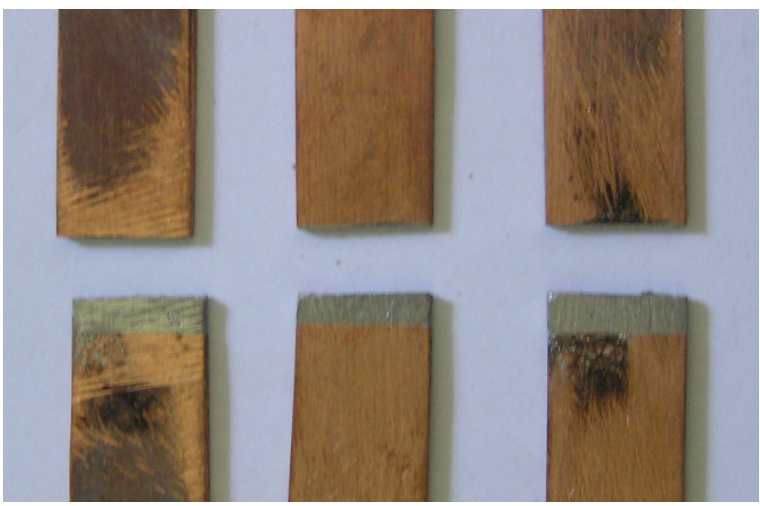

Fig. 10. Broken specimens after tensile testing

\subsection{Shear Strength of the Solder Joint}

Fig. 11 shows the shear strength of Sn-8Zn-3Bi solder joint in comparison with the $\mathrm{Sn}-37 \mathrm{~Pb}$. The shear strength of the Sn-8Zn-3Bi was found somewhat higher than that of $\mathrm{Sn}-37 \mathrm{~Pb}$. The shear strength of solder alloys was also increased as crosshead speed increased. At $0.1 \mathrm{~mm} / \mathrm{s}$ of crosshead speed, the shear strength of Sn-8Zn-3Bi was $29.3 \mathrm{MPa}$ and it increased up to $33.6 \mathrm{MPa}$ at a crosshead speed of $1 \mathrm{~mm} / \mathrm{s}$. The shear strength of $\mathrm{Sn}-8 \mathrm{Zn}-3 \mathrm{Bi}$ remains a little higher than $\mathrm{Sn}-37 \mathrm{~Pb}$ when crosshead speed changes.

It has been reported that the shear strength of $\mathrm{Sn}-8 \mathrm{Zn}-3 \mathrm{Bi}$ solder joint was higher than that of $\mathrm{Sn}-37 \mathrm{~Pb}$, the shear strength of Sn-8Zn-3Bi solder joint was as high as $68 \mathrm{MPa}$ [21]. It also reported that the shear strength of the joint is decreasing as the thickness of solder layer increases. The value of $68 \mathrm{MPa}$ was for the joint with the thickness of solder layer is $20 \mu \mathrm{m}$ [21]. In this work, the thickness of solder layer was around $1 \mathrm{~mm}$, almost 5 times the thickness reported, and thus, resulted in lower shear strength of the solder joint. 


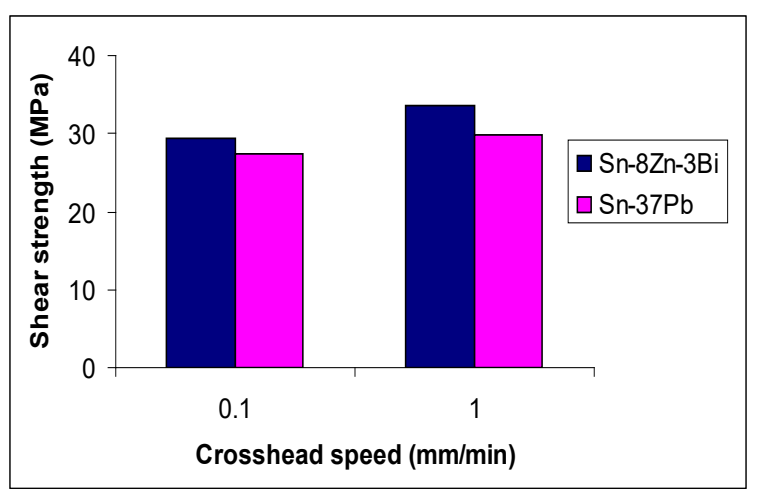

Fig. 11. Shear strength of solder alloys

\section{Conclusion}

Thermal and mechanical properties of the Sn-8Zn-3Bi solder alloy and the Sn-8Zn-3Bi joints were investigated in order to evaluate the workability of the alloy in comparison with the traditional $\mathrm{Sn}-37 \mathrm{~Pb}$.

The results show that the melting (liquidus) temperature of Sn- $8 \mathrm{Zn}-3 \mathrm{Bi}$ was $195^{\circ} \mathrm{C}$, the CTE of Sn- $8 \mathrm{Zn}-3 \mathrm{Bi}$ was $22.2 \times 10^{-6} \mathrm{~K}^{-1}$ in the temperature range of $30-130{ }^{\circ} \mathrm{C}$. At the same testing condition, both tensile and shear strength of Sn-8Zn-3Bi joints were higher than those of $\mathrm{Sn}-37 \mathrm{~Pb}$. The stress-strain curve indicated that the $\mathrm{Sn}-8 \mathrm{Zn}-3 \mathrm{Bi}$ joints were brittle whilst the $\mathrm{Sn}-37 \mathrm{~Pb}$ joints were ductile. The results indicated that the gaps between their melting temperature were relatively small, the melting temperature of $\mathrm{Sn}-8 \mathrm{Zn}-3 \mathrm{Bi}$ was just approx. $12{ }^{\circ} \mathrm{C}$ higher. Such a small gap could be easily overridden in the soldering process and thus, easing the process of replacing Sn-37Pb with Sn-8Zn-3Bi. The Sn-8Zn-3Bi also possesses higher mechanical properties, this is an important factor ensuring the strength of the solder joint. The CTE mismatch between $\mathrm{Sn}-8 \mathrm{Zn}-3 \mathrm{Bi}$ and $\mathrm{Sn}-37 \mathrm{~Pb}$ was also small, this is another factor ensuring the reliability of the joints.

\section{References}

[1] Ogunseitan, Oladele A., Public health and environmental benefits of adopting lead-free solders, The Journal of the Minerals, Metals \& Materials Society, Vol. 59, pp. 12-17, 2007.

https://doi.org/10.1007/s11837-007-0082-8

[2] K.N. Tu and K. Zeng, Tin-lead ( $\mathrm{SnPb})$ solder reaction in flip chip technology, Materials Science and Engineering Reports R, Vol. 34, pp. 1-58, 2001. https://doi.org/10.1016/S0927-796X(01)00029-8

[3] Howard H. Manko, Solders and Soldering, 4th edition, New York, USA: McGRAW-HILL, 2001.

[4] Abtew Mulugeta, Selvaduray Guna, Lead-free solders in microelectronic, Materials Science and Engineering Reports, Vol. 27, pp. 95-141, 2000. https://doi.org/10.1016/S0927-796X(00)00010-3

[5] Seung Wook Yoon, Won Kyoung Choi, Hyuck Mo Lee, Calculation of surface tension and wetting properties of sn-based solder alloys, Scripta Materialia, Vol. 40, No. 3, pp. 297-302, 1999.

https://doi.org/10.1016/S1359-6462(98)00417-5

[6] Mario F. Arenas, Viola L. Acoff, Contact Angle Measurements of Sn-Ag and Sn-Cu Lead-Free Solders on Copper Substrates, Journal of Electronic Materials Vol. 33, No. 12, pp. 1452-1458, 2004. https://doi.org/10.1007/s11664-004-0086-x

[7] E.A. Howell, C.M. Megaridis, M. McNallan, Dynamic surface tension measurements of molten $\mathrm{Sn} / \mathrm{Pb}$ solder using oscillating slender elliptical jets, International Journal of Heat and Fluid Flow, Vol. 25, pp. 91-102, 2004.

https://doi.org/10.1016/j.ijheatfluidflow.2003.10.003

[8] Mario F. Arenas, Min He, Viola L. Acoff, Effect of flux on the wetting characteristics of $\mathrm{SnAg}, \mathrm{SnCu}, \mathrm{SnAgBi}$, and $\mathrm{SnAgCu}$ lead-free solders on copper substrates, Journal of Electronic Materials, Vol. 35, No. 7, pp. 1530-1536, 2006. https://doi.org/10.1007/s11664-006-0144-7

[9] Jae-Ean Lee, Keun-Soo Kim, Masahiro Inoue, Junxiang Jiang, Katsuaki Suganuma, Effects of $\mathrm{Ag}$ and $\mathrm{Cu}$ addition on microstructural properties and oxidation resistance of $\mathrm{Sn}-\mathrm{Zn}$ eutectic alloy, Journal of Alloys and Compounds, Vol. 454, pp. 310-320, 2008. https://doi.org/10.1016/j.jallcom.2006.12.037

[10] H. Y. Guo, J. D. Guo, and J. K. Shang, Influence of thermal cycling on the thermal resistance of solder interfaces, Journal of Electronic Materials, Vol. 38, pp. 2470-2478, 2009. https://doi.org/10.1007/s11664-009-0857-5

[11] H. Mavoori, J. Chin, S. Vaynman, B. Moran, L. Keer, M. Fine, Creep, stress relaxation and plastic deformation in $\mathrm{Sn}-\mathrm{Ag}$ and $\mathrm{Sn}-\mathrm{Zn}$ eutectic solders, Journal of Electronic Materials, Vol. 26, pp. 783-790, 1997. https://doi.org/10.1007/s11664-997-0252-z

[12] Song J.M., Lan G.F., Lui T.S., Chen L.H., Microstructure and tensile properties of Sn-9Zn-xAg lead-free solder alloys, Scripta Materialia, Vol. 48, pp. 1047-1051, 2003. https://doi.org/10.1016/S1359-6462(02)00647-4

[13] Chang Tao-Chih, Wang Moo-Chin, Hon Min-Hsiung, Morphology and adhesion strength of the Sn-9Zn$3.5 \mathrm{Ag} / \mathrm{Cu}$ interface after aging, Journal of Crystal Growth, Vol. 263, pp. 223-231, 2003. https://doi.org/10.1016/j.jcrysgro.2003.05.002

[14] Shohji Ikuo, Gagg Colin, Plumbridge William J., Creep properties of Sn-8Zn-3Bi lead-free alloy, Journal of Electronic Materials, Vol. 33, No. 8, pp. 923-927, 2004. https://doi.org/10.1007/s11664-004-0222-7

[15] Chiu M.Y., Wang S.S., Chuang T.H., Intermetallic compounds formed during interfacial reactions between liquid Sn-8Zn-3Bi solders and Ni substrates, Journal of Electronic Materials, Vol. 31, No. 5, pp. 494-499, 2002. https://doi.org/10.1007/s11664-002-0105-8

[16] Shohji Ikuo, Gagg Colin, Plumbridge William J., Creep properties of Sn-8Zn-3Bi lead-free alloy, Journal of Electronic Materials, Vol. 33, No. 8, pp. 923-927, 2004. https://doi.org/10.1007/s1 1664-004-0222-7 
[17] Duong Ngoc Binh, Contact angle of Sn-8Zn-3Bi leadfree solder alloy on copper substrate, Journal of Science and Technology. Vol. 146, pp. 49-53, 2020. https://doi.org/10.51316/30.7.9

[18] Fleszar M.F., Lead-tin solder characterization by differential scanning calorimetry, Thermochimica Acta, Vol. 367-368, pp. 273-277, 2001.

https://doi.org/10.1016/S0040-6031(00)00671-7

[19] Kim K.S., Huh S.H., Suganuma K., Effects of cooling speed on microstructure and tensile properties of SnAg-Cu alloys, Materials Science and Engineering: A, Vol. 333, pp. 106-114, 2002.

https://doi.org/10.1016/S0921-5093(01)01828-7
[20] Shohji Ikuo, Yoshida Tomohiro, Takahashi Takehiko, Hioki Susumu, Tensile properties of Sn-Ag based leadfree solders and strain rate sensitivity, Materials Science and Engineering A, Vol. 366, pp. 50-55, 2003. https://doi.org/10.1016/j.msea.2003.09.057

[21] Akio Hirose, Hiroto Yanagawa, Eiichi Ide \& Kojiro F. Kobayashi, Joint strength and interfacial microstructure between $\mathrm{Sn}-\mathrm{Ag}-\mathrm{Cu}$ an $\mathrm{Sn}-\mathrm{Zn}-\mathrm{Bi}$ solders and $\mathrm{Cu}$ substrate, Science and Technology of Advanced Materials, Vol. 5, No. 1-2, pp. 267-276, 2004. https://doi.org/10.1016/j.stam.2003.10.024 